\title{
The Effect of Time Management on Learning Achievement of Students Jagad 'Alimussirry
}

\author{
Sholaita ${ }^{1}$, R Rahmatika $^{2}$, L Arilia ${ }^{3}$ \\ ${ }^{1}$ Departmen of Management, State University of Surabaya \\ ${ }^{2}$ Department of Biology, Universitas Negeri Malang \\ ${ }^{3}$ Department of Islamic Economic, State University of Surabaya \\ Email: sholaita20@gmail.com
}

\begin{abstract}
Function education in the view of Islam is not much different with the goal of national education, where education serves to improve the competency of an individual as a learner. There are two factors that influence the learning outcomes of an individual, the first is internal factors and the second is external factors. The purpose of this study was to determine the effect of time management on the achievement of students learning Islamic boarding school Jagad 'Alimussirry. The research method carried out in this study is the statistical method. The instrument test technique in this study was to test the validity and reliability while the data analysis technique used the linearity test. Hypothesis testing uses Partial Test ( $\mathrm{T}$ Test), coefficient of determination and simple linear regression analysis. The results obtained in the research that have been carried out without going through or using treatment that can be applied in the form of time management training, the results of statistical testing using simple linear regression analysis techniques can be stated that time management does not significantly influence students achievement in Jagad 'Alimussirry Islamic boarding school.
\end{abstract}

\section{Keywords: Time Management, Learning Achievement, Education}

\section{INTRODUCTION}

Function education in the view of Islam is not much different with the goal of national education, where education serves to improve the competency of an individual as a learner. In the process of achieving educational goals, an individual who plays a role as a student can be directed to formal and informal education.

According to Law No.20 of 2003 concerning the National education system, education is a conscious and planned effort to realize the atmosphere and learning process so that individuals or students can develop their potential to have a religious spiritual power, intelligence, personality, noble character, selfcontrol and skills that are useful for themselves, society, nation, religion and country.
There are two factors that influence the learning outcomes of an individual, the first is internal factors and the second is external factors. Where internal factors are everything that is inherent in the individual who can influence the achievement of learning outcomes, such as talent, interest, motivation and intelligence. While external factors are everything that comes from outside the individual either directly or indirectly can influence individuals in achieving learning outcomes such as the family environment, Islamic boarding schools and society.

Time management is a skill that is related to all forms of efforts and individual actions carried out in a planned manner so that the individual can make the best use of time. Time management can reduce the tendency of 
individuals to procrastinate on a job, help individuals determine the priorities of an activity, and help the process of evaluating the results of work. In addition, time management can prevent and minimize the occurrence of two jobs carried out at the same time.

\section{METHOD}

This research is included in quantitative research which emphasizes numerical data (numbers) that are processed using statistical methods. The subjects of this study were students who were students in the Jagad 'Alimussirry Islamic boarding school . This type of research is explanatory research, where explanatory research is a research study that explains the causal relationship between independent variables $(\mathrm{X})$ to the dependent variable $(\mathrm{Y})$. The variables referred to here are time management variables and student learning achievements. The analysis used is simple linear regression analysis, where this analysis is used because in this study there is only one independent variable and one dependent variable.

This research was conducted in the Jagad 'Alimussirry Islamic boarding school, where the boarding school consisted of three huts, each of which had a different location, namely I boarding school located in Jetis Agraria 1 No.20, boarding school II located in Jetis Kulon V1 / 16A, and III boarding schools are located in East Ket PPP VB No 3-4, Surabaya.

Samples taken from the population must be truly representative (representative). Where the number of samples taken in this study is 50.

The instrument test technique in this study was to test the validity and reliability while the data analysis technique used the linearity test. Hypothesis testing uses Partial Test (T Test), coefficient of determination and simple linear regression analysis.

\section{RESULT AND DISCUSSION}

Adebayo's research (2015), gave results that time management had an effect on learning achievement [1] . This is supported by the results of Dr. Maysoon Al-Zoubi (2016), which states that time management affects learning achievement significantly [2] . Similarly, the results of the research of Muhammad Saqib Khan (2015) and Wasan Siddiq Yahya Alsalem et al. (2017). Whereas the research conducted by Odai Falah Mohammad Alghaswyneh, (2015) gives different results, namely that time management does not significantly affect learning achievement [3] .

Based on research that has been carried out without going through or using treatment that can be applied in the form of time management training, the results of statistical testing using simple linear regression analysis techniques can be stated that time management does not significantly influence the achievement of students in Islamic boarding schools in Alimussirry. This makes it possible that there are variables other than time management that have an influence on the learning achievement of students in the Jagad 'Alimussirry Islamic boarding school, as well as the level of religiosity, physical health, and so on. Although in general time management is one of the most important things in the success of education.

\section{CONCLUSION}

1) Students of Islamic boarding school Jagad A'limussirry less manage the time well

2) There is no influence between time management on the achievements of the students of the Jagad 'Alimussirry Islamic boarding school

\section{REFERENCES}

[1] Adebayo "Time Management and Students Academic Performance in Higher Institutions, Nigeria - A Case Study of Ekiti State", International Research in Education, Vol. 3, No. 2, 2015.

[2] Dr. Maysoon Al-Zoubi, "The Effect of the Time Management Art on Academic Achievement among High School 
Students in Jordan" Journal of Education and Practice, Vol.7, No.5, 2016.

[3] Odai Falah Mohammad Alghaswyneh, "The Role of Time Management and its Impact on Case A Students' Academic Achievement (Students at Northern Borders University)", International Research Journal of Finance and Economics Press., ISSN 1450-2887, Issue 136, 2015. 